\title{
EMOTIONAL POTENTIAL OF PHRASEOLOGICAL UNITS IN THE TATAR LANGUAGE
}

\author{
POTENCIAL EMOCIONAL DE UNIDADES FRASEOLÓGICAS NA LÍNGUA TARTAR \\ POTENCIAL EMOCIONAL DE LAS UNIDADES FRASEOLÓGICAS EN EL LENGUAJE \\ TATAR
}

\author{
Firuza Ramzelovna SIBGAEVA ${ }^{1}$ \\ Raushaniya Sagdatzyanovna NURMUKHAMETOVA ${ }^{2}$ \\ Madina RASHIDOVNA ${ }^{3}$ \\ Elvan CAFAROV ${ }^{4}$
}

\begin{abstract}
Emotions have a huge impact on human life. One of the fundamental factors in managing human behavior is emotion. The article is devoted to a brief review of the expression of emotion in the Tatar language. The problem of studying the linguistic picture of the world is closely connected with the problem of conceptual picture of the world that displays the specifics of man and his existence, his relationship with the world, the conditions of his existence. Language picture of the world explicits different world-view and shows the General picture of the world. Human activity, which includes the symbolic, i.e. cultural, universe as an integral part, is both universal and national-specific. These properties determine both the originality of the language picture of the world and its universality. On the basis of modern trends, new directions in linguistics are being formed taking the role of the emotions into consideration: sociolinguistics aspect of emotions, etc., The cognitive aspect of emotions, the psycholinguistic aspect of emotions, and the linguostylistic aspect of emotions. The study presents the authors' classification of emotionally rich language units. In the article, the authors also offer their vision of the future prospects of studying the topic.
\end{abstract}

KEYWORDS: Tatar language. Emotional world. Linguoculturology. Emotional concept. Emotionality.

RESUMO: As emoções têm um grande impacto na vida humana, sendo um dos fatores fundamentais no gerenciamento do comportamento humano. $O$ artigo é dedicado a uma breve revisão da expressão da emocionalidade na língua tártara. O problema de estudar a imagem linguística de mundo está intimamente ligado ao problema da imagem conceitual de mundo que mostra as especificidades do homem e sua existência, sua relação com o mundo, as

\footnotetext{
${ }^{1}$ Kazan Federal University (KPFU), Kazan - Russia. Associate Professor of the Department of Russian as a Foreign Language, Institute of Philology and Intercultural Communication. $\mathrm{PhD}$ in Philology. ORCID: https://orcid.org/0000-0002-9561-160X. Email: Firuzars@mail.ru

2 Kazan Federal University (KPFU), Kazan - Russia. Associate Professor of the Department of Russian as a Foreign Language, Institute of Philology and Intercultural Communication. $\mathrm{PhD}$ in Philology. ORCID: https://orcid.org/0000-0002-7525-2726. E-mail: rsagadat@yandex.ru

${ }^{3}$ Kazan Federal University (KPFU), Kazan - Russia. Associate Professor of the Department of Russian as a Foreign Language, Institute of Philology and Intercultural Communication. PhD in Philology. ORCID: https://orcid.org/0000-0002-7242-334X. E-mail: m-sattarova@mail.ru

${ }^{4}$ Azerbaijan State Pedagogical University (ADPU), Baku - Azerbaijan. Associate Professor. PhD in Philology. ORCID: https://orcid.org/0000-0003-4419-4321. E-mail: elvancafarov78@mail.ru
} 
condições de sua existência. A imagem da linguagem do mundo explícita uma visão de mundo diferente e mostra a imagem geral do mundo. A atividade humana, que inclui o universo simbólico, isto é, cultural, como parte integrante, é universal e especificamente nacional. Essas propriedades determinam tanto a originalidade da imagem linguística do mundo quanto sua universalidade. Com base nas tendências modernas, novas direções na linguística estão sendo formadas que considerem as emoções: o aspecto sociolinguístico das emoções, etc., bem como, o aspecto cognitivo das emoções, o aspecto psicolinguístico das emoções e o aspecto linguoestilístico das emoções. O estudo fornece a classificação de unidades de linguagem emocionalmente ricas. No artigo, os autores também oferecem sua visão sobre as perspectivas futuras do estudo desse tema.

PALAVRAS-CHAVE: Linguagem tártara. Mundo emocional. Linguoculturologia. Conceito emocional. Emocionalidade.

RESUMEN: Las emociones tienen un gran impacto en la vida humana. Por este motivo, comenzaron a prestarle atención desde la antigüedad. Uno de los factores fundamentales en el manejo del comportamiento humano es la emoción. El artículo está dedicado a una breve revisión de la expresión de la emotividad en el idioma tártaro. El problema de estudiar la imagen lingüística del mundo está estrechamente relacionado con el problema de la imagen conceptual del mundo que muestra los detalles del hombre y su existencia, su relación con el mundo, las condiciones de su existencia, la imagen del mundo explícita del lenguaje. diferente visión del mundo y muestra la imagen general del mundo. La actividad humana, que incluye el universo simbólico, es decir, cultural, como parte integral, es tanto universal como nacional. Estas propiedades determinan tanto la originalidad de la imagen lingüistica del mundo como su universalidad. Sobre la base de las tendencias modernas, se están formando nuevas direcciones en lingüistica que consideran las emociones: aspecto sociolingüístico de las emociones, etc., el aspecto cognitivo de las emociones, el aspecto psicolingüistico de las emociones y el aspecto lingüístico de las emociones. El estudio da la clasificación del autor de unidades de lenguaje emocionalmente ricas. En el artículo, los autores también ofrecen su visión de las perspectivas futuras del estudio de este tema.

PALABRAS CLAVE: Lengua tártara. Mundo emocional. Lingüoculturología. Concepto emocional. Emocionalidad.

\section{Introduction}

No sphere of human life - spiritual, intellectual, or physical- is possible without the participation of emotions. However, for a long time, they have remained out of the field of researchers. Psychologist N. N. Lange writes about this: "Feeling takes the place of Cendrillon in psychology, unloved, persecuted and forever robbed in favor of older sisters - "mind" and "will" (SAFIULLINA, 1999). This formulation can also be attributed to linguistics, because in linguistics for a long time the formal prevailed over the content. However, in the twentieth century, the attention of linguists switches from "how language is arranged to how it functions" (AYUPOVA, 2015). 
The purpose of this article is to study the expression of emotionality in the Tatar language using lexical units of the Tatar language. Based on the goal, it is assumed to solve the following tasks: coverage of a brief history of the issue; description of the state of Tatar emotional vocabulary, determining trends in the development of this topic.

The object of this research is emotionality in the Tatar language, expressed in lexical units. The subject of the research is semantic emotionality in the Tatar language.

The scientific novelty consists in the fact that for the first time it consistently conducts a multi-aspect analysis of language tools in the creation of emotive and expressive ways, as well as a detailed analysis of the components of meaning, determines their role in the expression of emotionality.

Modern science also takes into account the importance of the emotional sphere of a person. This is evidenced by the fact that the issues of emotions are considered by different authors in different aspects. Thus, emotions and emotionality, which have a psychological nature, are the object of study of psychology (ISANBET, 1989; ISANBET, 1990; SAFIULLINA, 2001). Emotions are the object of study of philosophy: the two-sided nature of the word, i.e. the presence of its internal and sound forms is first mentioned in the works of $\mathrm{V}$. von Humboldt. Ortega y Gasset, F. Wheelwright, V. V. Vinogradov, N. A. Lukyanova, I. A. Sternin, V. N. Telia, A. A. Ufimtseva, V. I. Shakhovsky, etc.

The problem of the expression of emotions in the Tatar language has not been sufficiently studied, it has only been touched upon in works devoted to other linguistic problems. For example, the influence of emotions on various levels of language is covered in the works of I. B. Bashirova, G. R. Galiullina, E. N. Denmukhametova, H. R. Kurbatov, F. S. Safiullina. Recently, under the authorship of M. Z. Zakiev, G. R. Galiullina, R. F. Fattakhova, A. K. Bulatova, the first volume of the three-volume book "Tatar lexicologiyase" was published (SAFIULLINA, 1999; YERBULATOVA; KIRILLOVA; SAHIN, 2019; KASEMU et al., 2018; FAKHRIEVA; KIRILLOVA; ALKAYA, 2017).

The linguistic and cultural aspect of emotionality in Tatar linguistics is considered in the works of L. K. Bayramova and R. R. Zamaletdinova (ZAMALETDINOV; GABDRAKHMANOVA; ZAMALETDINOVA, 2018).

In accordance with the nature and volume of the material studied, various methods and techniques are combined in the work. A versatile approach should take into account since emotionality is "a mental phenomenon and therefore should be investigated by psychological methods, because this phenomenon is both speech and language, so among the methods of its research should be methods" that consider emotionality "on the language material, and methods 
that explore it in the text" (YUISUFUVA et al., 2017; GILAZETDINOVA; SALAKHOVA, 2018).

\section{Methods}

Taking into account the specificity of the subject of research, the work uses a set of linguistic and cognitive methods, as well as separate techniques of psycholinguistic and linguoculturological methods.

The main method of research is the descriptive method, which includes such techniques as the study of factual material, generalization, interpretation and classification.

The component analysis method is used for differentiated research of word semantics levels. However, the division of word semantics into separate components is "only a dead product of scientific analysis" (MUGTASIMOVA; NABIULLINA; DENMUKHAMETOVA; BERKER, 2017). Therefore, the work also uses a stylistic method that considers the interaction of words in the text.

The psycholinguistic method is used when considering the emotional potential of lexemes in certain situations that are revealed in the context.

In order to identify the peculiarities of the Tatar mentality at the time of using a particular lexical unit, a synthesis of cognitive and linguistic-cultural methods was used.

\section{Results and discussion}

At the moment of creative reinterpretation of an event, a person compares their emotions with the more or less familiar material world. Therefore, emotions belong to the spiritual world, but have a close connection with the material world. Emotions have the same qualities as material objects. Emotions have the following qualities: speed, temperature, weight.

Thus, emotions are characterized by the same qualities as objects of material realityspeed, temperature, weight. Emotion is an object of the spiritual world, but it finds ways to refract in material reality through behavior, memories, dialogue, beautiful description, comparison, and news. It follows that the material world and the spiritual world are closely interrelated.

The relationship of emotions with the tangible nature, the material world also perceives that the emergence and change of emotions is affected by the developments in the outside world: positive or negative behavior of an entity towards another entity; memories; words 
addressed to the entity to another entity in the form of a dialogue, beautiful description; opinion; comparison; news.

The imagery of idioms is reflected in the material shell of this unit of language. An imaginative idiom consists, as a rule, of at least two lexemes, the meaning of which can be conveyed in one word, but the new lexical unit, in this case, loses its imagery. For example: avyz peshu - yalgyshu 'mistaken', avyz tursajtu - upkeleu 'mistaken', bohar ishege - yalkau 'lazy person', bua buarlyk - kup 'many', der-der kilu - kaltyrau 'tremble', ikmekter eger - ant 'oath', ikmek shurlege - avyz 'mouth', kalem iyalere - yazuchylar 'writers', kolakka katy sangyrau 'deaf', memi avyz - buldyksyz 'stupid', nesel agachy - shejere 'family tree', tel yasheru - deshmeu 'silent', shygyrym tuly - tutyrylgan 'many'. Ярким свидетельством доминирования образного микрокомпонента в качестве доминирующего компонента является следующий пример: I Rejhane apa, Ibrahim abyjny kuz karasy kebek saklap kyna yashegensender, ejeme! (And, Raihana apa, you probably cherished Ibrahim Aby as the Apple of your eye, but after all!) (A. Akhmetgalieva). Here is a figurative idiom "kuz karasy kebek saklarga" which means that the subject of speech protects her husband as the apple of her eye and this figurative positive relationship between the spouses generates positive emotionality. Thus, the presence of semantics in the semantics of sema imagery is one of the important moments in the emergence of its emotionality.

In the course of studying modern Tatar linguists identified the following idioms that Express emotionality, characteristic only of the Tatar language: ir jerege - tepsez koe; edeple kyz - sedeple; alty yash'lek chitten kajtsa, altmysh yash'lek kure kiler; kunel kuze, selek kebek bulu, sirat kuperen uterge, helel/ heram ejber,sabyr tebe - sary altyn.

In the modern Tatar language, the use of idioms achieves the emotional potential of the context, bringing to the fore the national color and mentality of the Tatar people. Let's look at these examples: - Hush kilden memleketebezge, Andrej kenez. Beznen halykta kanatly ber suz bar: «Alty yash'lek chitten kajtsa, altmysh yash'lek kure kiler», - di (Welcome to our country, Prince Andrew. We have a popular expression: "If a six-year-old returns from a foreign country, a sixty-year-old comes to see him") (V. Imamov). This idiom expresses the Tatar national custom of greeting a person who has returned home from a foreign country with respect and honor. The emotionality of the idiom is formed due to the SEMA of intensity expressed by agerelated opposition alty yash'lek - altmysh yash'lek. The main core of Tatar culture is the tradition of respect for elders. In this Tatar idiom, the opposite is observed - the elder gives honor to the younger. Given the national traditions of the Tatar people, based on respect for elders, and due to the reverse of the picture when a senior is having the youngest age, when the 
latter returned from exile to their homeland, and expressed positive emotions towards the older generation, thus creating positive emotion idioms.

The idiom is specific and unique to the modern Tatar language kunel kuze. The peculiarity of this idiom and its emotional nature are reflected in the Tatar folk proverb kunel kuze kurmese, mangaj kuze - botak tishege (A person does not see what he does not want to see, or Rus. analog: No one is so deaf as someone who does not want to hear). Phraseological unit kunel kuze is found in modern Tatar prose. For example: In mehime - keshenen kunel kuze sukyr bulmasyn, baryna shekrana ite belsen. (The most important thing is that a person's soul is sighted, that a person is grateful), (F. Bayramova). Kunel kuzkejleremne achtyn, Hodaem, inde monnan son rehmetennen tashlama (You opened the eyes of my soul, God, and from now on, please don't leave me), (A. Akhmetgalieva). Bu inde kunel kuzenen euvelden uk men deumele belen sukyrayuynnan kileder (Most likely, this is all due to the blindness of the eyes of the soul) (A. Halim). Helim, poshmas kyyafette, kunel kuze belen any ishekke kader ozatyp kaldy, (Halim, without giving mind, feeling soul, walked her to her door) (G. Gilmanov). In these examples, the ability of a person to see as much as possible with their eyes, but with their soul, is evaluated as a positive quality. Accordingly, the ability of a person to see the soul has generated positive emotions.

\section{Summary}

The emotionality of the modern Tatar language is most clearly revealed through the picturesqueness, skill of the language of Tatar writers to reflect the depth of the emotional world of representatives of the Tatar ethnic group.

Emotionality, which is the expression of emotions by the addressee and the addressee, or both at the same time, and their reflection in writing or speech, can be realized in one of its two varieties - emotivism or expressiveness.

An important role in determining emotionality is played by the components of the word meaning, namely the connotation components - "imagery", "evaluation"," emotionality"," intensity", which in various combinations generate emotivism or expressiveness. Individual components of connotation may not create emotivism and expressiveness.

The specificity of emotionality in the modern Tatar language is formed by factors that determine the individual path of development of the Tatar people (history, traditions, culture). 


\section{Conclusions}

This research is an initial stage on the existing topic, since only certain idioms of the Tatar language became the research material. This topic has the potential to explore other phraseological units of the Tatar language. For example, phraseological dictionaries of the Tatar language are an interesting object. There are quite a large number of them today, and they also belong to the segment of emotionally colored phraseological units of the Tatar language.

ACKNOWLEDGEMENTS: The work is performed according to the Russian Government Program of Competitive Growth of Kazan Federal University.

\section{REFERENCES}

AYUPOVA, R. A. Rol' paradoksov v formirovanii frazeologicheskoj edinicy kak lingvisticheskogo znaka. Philology and Culture, v. 4, n. 42, p. 35-40, 2015.

BERKER, K. Analysis of Turkic Students Verbal Expression Studies in Turkey Turkish Language by "Speaking Skill Assessment Scale". Tarih kultur ve sanat arastirmalari dergisi-journal of history culture and art research, v. 6, n. 2, p. 358-384, 2017.

FAKHRIEVA, L. K.; KIRILlOVA, Z. N.; ALKAYA, E. Metaphors in Russian Poetry Translations into Tatar. Journal of History Culture and Art Research, v. 6, n. 6, p. 153$158,2017$.

GILAZETDINOVA, G. K.; SALAKHOVA, R. R. Lexical-semantic groups of the verbs of motion in structurally different languages (On the material of the russian and the tatar languages). XLinguae, v. 11, n. 4, p. 32-44, 2018.

ISANBET, N. S. Frazeologicheskij slovar' tatarskogo yazyka. Kazan': Tatar. knizh. izd-vo, 366 s., Tatarsko-russkij frazeologicheskij slovar'. Kazan': Magarif, 2001. 1990. v 2-h t. T. II. $335 \mathrm{p}$.

ISANBET, N. S. Frazeologicheskij slovar'tatarskogo yazyka. Kazan': Magarif, 1989. V. 2. T. I.

KASEMU, S.; YUSUPOVA, A. S.; DENMUKHAMETOVA, E. N.; MUGTASIMOVA, G. R. Traditions of compiling bilingual dictionaries for turkic peoples. Amazonia Investiga, v. 7, n. 13, p. 156-161, 2018.

KHASANZYANOVA, G. I.; ISLAMOVA, E. A.; BOLGAROVA, R. M.; RAMI, I. Man in the mirror free association experiment. AD ALTA-Journal of Interdisciplinary Research, v. 8, n. 1, p. 190-192, 2018.

MUGTASIMOVA, G. R.; NABIULLINA, G. A.; DENMUKHAMETOVA, E. N. Paremiological fund of the Tatar people in the ethno-linguistic aspect. Life Science Journal, v. 11, n. 11, p. 409-412, 2014. 
SAFIULLINA, F. S. Serge tatars by body. Lexicology (yugary UCU yorty studentsare can). Kazan: Khater, 1999. 288 p.

SAFIULLINA, F. S. Tatarsko-russkij frazeologicheskij slovar'. Kazan': Magarif, 2001. 335 p.

VILDANOVA, R. R.; ZAMALETDINOV, R. R.; SATTAROVA, M. R.; ZAMALETDINOVA, G. F. Tatars names as a phenomenon of traditional culture. Astra Salvensis, v. 10, 2017.

YERBULATOVA, I. K.; KIRILLOVA, Z. N.; SAHIN, L. National and cultural realias of translations into tatar. Humanities \& Social Sciences Reviews, v. 7, n. 6, p. 984-987, 2019.

YUISUFUVA, Z.; YUSUPOVA, A. S.; MUGTASIMOVA, R.; Denmukhametova, E. N. Paroemiological units of the tatar language with culture-specific lexicon, Modern journal of language teaching methods. Astra Salvensis, v. 5, p. 109-115, 2017.

ZAMALETDINOV, R.; GABDRAKHMANOVA, F.; ZAMALETDINOVA, G. The language picture of the world of the tatars and the national image of the world. Herald NAMSCA, n. 3, p. 782-785, 2018. DOI: https://doi.org/10.32461/2226-3209.3.2018.171842

\section{How to reference this article}

SIBGAEVA, F. R.; NURMUKHAMETOVA, R. S.; RASHIDOVNA, M.; CAFAROV, E. Emotional potential of phraseological units in the tatar language. Rev. EntreLínguas, Araraquara, v. 7, n. esp. 1, p. 47-54, fev. 2021. e-ISSN: 2447-3529. DOI: https://doi.org/10.29051/el.v7iEsp1.14871

Submitted: $28 / 10 / 2020$

Required revisions: $19 / 12 / 2020$

Approved: 13/01/2021

Published: 28/02/2021 